Int. J. Dev. Biol. 66: 311-316 (2022)

https://doi.org/10.1387/ijdb.210234dr

\title{
Epithelial-endothelial transition and endothelial-mesenchymal transition
}

\begin{abstract}
DOMENICO RIBATTI*
Department of Basic Medical Sciences, Neurosciences and Sensory Organs, University of Bari Medical School, Bari, Italy

ABSTRACT The movement of continuous sheets of epithelial cells occurs during embryonic development, tissue repair, and cancer. Common to cellular and molecular principles of collective cell migration, invading cancers seem to reactivate embryonic pathways and patterns of cell movement. Epithelial cells possess the capability to become mesenchymal cells in a process called epithelial mesenchymal transition (EMT), which has been extensively studied and described. The aim of this article is to summarize the most recent literature data concerning less known epithelial-endothelial transition and endothelialmesenchymal transition.
\end{abstract}

KEYWORDS: epithelial-mesenchymal transition, epithelial-endothelial transition, endothelial-mesenchymal transition, morphogenesis, tumor growth

\section{Introduction}

The movement of continuous sheets of epithelial cells occurs during embryonic development, tissue repair, and cancer (Friedl and Gilmour, 2009). The different strategies of epithelial cell migration are likely to be related to physiological differences between cell types and are influenced by the environment through which cells must migrate. Epithelial cells have a clear apico-basal polarity with cell-matrix adhesion on their basal side and cell-cell adhesion on their apical side, and when epithelial cells undergo collective migration, they maintain part of their epithelial characteristics. Collective migration is one of the hallmarks of embryonic morphogenesis, while collective invasion is prevalent in many cancer types. Common to cellular and molecular principles of collective cell migration, invading cancers seem to reactivate embryonic pathways and patterns of cell movement.

Epithelial cells possess the capability to become mesenchymal cells in a process called epithelial mesenchymal transition (EMT) (Ribatti, 2017). During EMT, stable cell-cell junctions are disassembled, apico-basal polarity is lost, and migratory capabilities are enhanced. EMTs are classified into three types: type 1 , which occurs during embryonic development; type 2 , which is associated with adult tissue repair; and type 3 , which is involved in cancer progression (Kalluri and Weinberg, 2009; Zeisberg and Neilson, 2009). Cancers exhibit some degree of EMT during their progression, and epithelial tumors are the result of an EMT process, in which tumor cells lose their epithelial features, including cell adhesion and polarity, reorganize their cytoskeleton, and acquire a mesenchymal morphology and the ability to migrate.

Endothelial cell migration is essential to vasculogenesis and angiogenesis, and is directionally regulated by different stimuli, involving degradation of the extracellular matrix to enable progression of the migrating cells. It requires the activation of several signaling pathways that converge on cytoskeletal remodeling, and different regulatory mechanisms and factors control this process, including gradients of soluble factors, extracellular matrix-cell inter-

\begin{abstract}
Abbreviationsused in thispaper: aSMA,alphasmoothactin;CAFs,cancerassociated fibroblasts; CSCs, cancer stem cells; EET, epithelial endothelial transition; EGF, epidermal growth factor; EMT, epithelial mesenchymal transition; EndoMT, endothelial mesenchymal transition; ET-1, endothelin-1; FGF, fibroblast growth factor; FSP-1, fibroblast specific protein-1; HGF, hepatocyte growth factor; HIF1a,hypoxia inducible factor 1 alpha; MRTF-A, myocardin-related transcription factor-A; MMP, matrix metalloproteinase; MSCs, mesenchymal stem cells;PAR, protease activated receptor; PDGF, platelet derived growth factor; PECAM-1, platelet endothelial cell adhesion molecule-1; SCDF, stromal cell derived factor: TGF $\beta$, transforming growth factorbeta;TNFatumor necrosis factor alpha;TNBC, triple negative breast cancer; vascular endothelial cadherin,VE cadherin; VEGF, vascular endothelial growth factor; VEGFR, vascular endothelial growth factor; VM, vasculogenic mimicry.
\end{abstract}

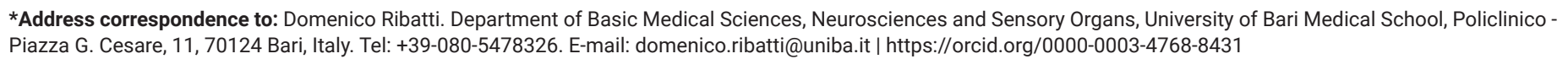

Submitted: 28 December, 2021; Accepted: 21 February, 2022; Published online: 21 February, 2022.

ISSN: Online 1696-3547, Print 0214-6282

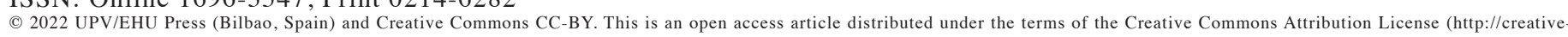

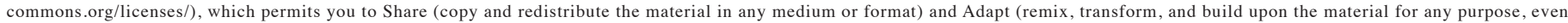

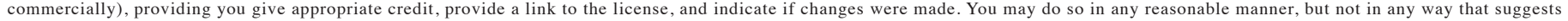
the licensor endorses you or your use. Printed in Spain. 
action and cell- cell interaction. Three types of cells constitute the new vasculature: tip cells, which migrate in response to gradients of vascular endothelial growth factor (VEGF); stalk cells, which proliferate and extend the vessels; and phalanx cells, which are quiescent and support the sprout (Ribatti and Crivellato, 2012). The aim of this article is to summarize the most recent literature data concerning the study of epithelial-endothelial transition and endothelial-mesenchymal transition by means of different in vitro and in vivo models, including cellular models, such as the use of genetic lineage tracing technology making it possible to follow endothelial cell lineage conversion in vivo, murine models, and patient bioptic specimen analysis.

\section{Epithelial-endothelial transition}

Epithelial endothelial transition (EET), a subtype of EMT, is a process of transformation of tumor epithelial cells in endothelial cells. Tumor cells lose their polarity and tight junctions, involving decreased expression of E-cadherin and occludin, and increased expression of vimentin, vascular endothelial (VE)-cadherin, fibronectin, and vitronectin (Sun et al., 2016). EET is also involved in kidney allograft fibrosis associated with tubular atrophy (Granata et al., 2020).

EET occurs during vasculogenic mimicry (VM), i.e. cancer cellderived channels like blood vessels, acting as alternative source of nutrient and oxygen supply and involved in tumor growth and invasion. In 1999, Maniotis and co-workers described this process in human melanoma for the first time, showing trans-differentiation of melanoma cells, which results in the formation of a chimeric vasculature composed of melanoma and endothelial cells (Maniotis et al., 1999). Since then, VM has been demonstrated in renal cell carcinoma, breast cancer, ovarian cancer, primary gallbladder cancer, esophageal squamous cell carcinoma, mesothelioma, alveolar rhabdomyosarcoma, and hepatocellular carcinoma (Cao and Qian, 2020).

During VM, epithelial-derived tumor cells differentiate into cell types expressing some endothelial markers, including VE-cadherin and vimentin. VM formation is promoted by transforming growth factor beta (TGF 3 ), and CXCL12/Stromal cell derived factor-1 (SDF-1) secreted by cancer associated fibroblasts (CAFs), which are involved in EET (Yang et al., 2016).

\section{Molecular pathways involved in EET}

An EMT transcription factor, Twist1, is also involved in EET (Sun et al.,2011). Under hypoxia, Twist1 translocates to the nucleus and binds to VE-cadherin promoter to induce EET and VM in hepatocellular carcinoma (Sun et al., 2010). Similarly, hypoxia-associated Twist1 overexpression upregulates VE-cadherin in MDA-MB-231 triple negative breast cancer (TNBC) cells, and induces these cells to generate cancer stem cells (CSCs) and promote VM in Matrigel (Zhang et al., 2014). In hepatocellular carcinoma, the Bcl2/Twist1 complex leads to transcriptional activation of different genes that induce EET and VM (Sun et al., 2011). Moreover, in hepatocellular carcinoma, overexpression of Twist1 under hypoxic conditions increased matrix metalloproteinases- 2 and -9 (MMP-2 and MMP9) expression and VM (Sun et al., 2011). In addition, protease-activated receptor-1 (PAR-1) promotes EET through Twist1 in hepatocellular carcinoma by up-regulating Twist 1 both in vitro and in vivo through
TABLE 1

\section{LOSS OF ENDOTHELIAL MARKERS AND ACQUISITION OF MESENCHYMAL MARKERS DURING ENDOMT}

\begin{tabular}{ll}
\hline Endothelial markers & CD31 \\
& Platelet endothelial cell adhesion molecule-1 (PECAM-1) \\
& Tie-2 \\
& Vascular endothelial (VE)-cadherin \\
& N-cadherin \\
Mesenchymal markers & Fibroblast specific protein-1 (FSP-1) \\
& Alpha smooth muscle actin (aSMA) \\
& Types I/III collagen \\
\hline
\end{tabular}

thrombin binding (Xiao et al., 2018). Finally, these data indicate that a significant correlation between the expression level of VMrelated proteins, including VEGF receptor-1 and -2 (VEGFR-1 and VEGFR-2), VE-cadherin, vimentin, MMP-2 and MMP-9, and PAR-1, has been found in hepatocellular carcinoma bioptic specimens (Xiao et al., 2018).

\section{Endothelial-mesenchymal transition}

Endothelial cells may de-differentiate into mesenchymal stemlike cells (MSCs) and acquire the characteristics of multipotent cells (Medici and Kalluri, 2012). This process has been defined as endothelial to mesenchymal transition (EndoMT). During EndoMT, endothelial cells loss endothelial markers and acquire mesenchymal markers (Table 1).

EndoMT takes place during embryogenesis (Timmerman et al., 2003), aorta development, pulmonary artery development, cardiogenesis and vasculogenesis (Arciniegas et al., 1989; 2005).

During cardiogenesis, endothelial cells undergo EndoMT, invade the cardiac jelly, and generate the cardiac cushion (precursors of the semilunar valves) (Kovacic et al., 2012). During the formation of heart valves, endocardial cells show morphological alterations, including cellular hypertrophy, lateralization of the Golgi apparatus and loss of cell polarity (Markwald and Fizharris, 1975). During the formation of the endocardial cushion in the chick embryo, cardiac endothelial cells show phenotypic changes correlated with alpha smooth actin expression (aSMA) (Nakajima et al., 1997). Epicardial cells also undergo EMT to give rise to smooth muscle cells, interstitial cardiac stromal cells and potentially a sub-population

TABLE 2

\section{PATHOLOGICAL CONDITIONS IN WHICH ENDMT IS INVOLVED}

\begin{tabular}{|c|c|}
\hline Pathological conditions & References \\
\hline Pulmonary arterial hypertension & $\begin{array}{l}\text { Arcinegas et al., 2007; Hopper et al., 2016; } \\
\text { Tuder et al., } 1994\end{array}$ \\
\hline Atherosclerosis & Souilhol et al., 2018 \\
\hline Cardiac fibrosis & Widyantoro et al., 2010; Zeisberg et al., 2007a \\
\hline Dermal fibrosis & Manetti et al., 2017 \\
\hline Radiation-induced rectal fibrosis & Mintet et al., 2015 \\
\hline Myocardial infarction & Tombor et al., 2021 \\
\hline Pulmonary fibrosis & Hashimoto et al., 2010 \\
\hline Renal fibrosis & $\begin{array}{l}\text { Li et al., 2009; Xavier et al., 2014; } \\
\text { Zeisberg et al., } 2008\end{array}$ \\
\hline Cancer & Fan et al., 2017; Zeisberg et al., 2007b \\
\hline $\begin{array}{l}\text { Systemic sclerosis-associated interstitial lung } \\
\text { disease }\end{array}$ & Mendoza et al., 2015 \\
\hline Diabetes mellitus & Li et al., 2009; Cao et al., 2014 \\
\hline
\end{tabular}


TABLE 3

\section{DIFFERENT TYPES OF CANCERS IN WHICH ENDOMT IS INVOLVED}

\begin{tabular}{ll} 
Types of cancers & References \\
\hline Melanoma & Zeisberg et al. 2007b \\
Colorectal cancer & Fan et al., 2018; Yamada et al., 2019; \\
Pancreatic cancer & Fan et al., 2019 \\
Lung cancer & Choi et al., 2018; Kim et al., 2019 \\
Glioblastoma & Huang et al., 2016, 2020; Liu et al., 2018 \\
Esophageal cancer & Nie et al., 2014 \\
\hline
\end{tabular}

of endothelial cells (Kovacic et al., 2012). EndoMT contributes to the vascular remodeling and neo-intimal formation that arises following vein graft transplantation into the arterial circulation (Cooley et al., 2014).

EndoMT is involved in different pathological conditions (Table 2). Moreover, EndoMT is involved in different types of cancers (Table 3). Tumor-induced EndoMT is associated with the activation of pro-inflammatory pathways in endothelial cells (Nie et al., 2014). Endothelial cells undergoing tumor-induced EndoMT express higher levels of the VEGF gene (Hog et al., 2018). Moreover, EndoMT contributes to metastatic extravasation and intravasation (Dudley et al., 2012).

\section{Molecular pathways involved in EndoMT}

Several signaling pathways are involved in EndoMT, including Notch, TGF $\beta$, WNT, fibroblast growth factor (FGF) and epidermal growth factor (EGF) (Man et al., 2018). TGF $\beta$ is a potent activator of the EndoMT program in developmental and pathological settings (Arciniegas et al., 1992; Pardali et al., 2017; Xiao et al., 2015; Ma et al., 2021). Notch promotes TGF $\beta$-mediated EndoMT in embryonic heart through the induction of Snail-1 expression and a down-regulation of VE-cadherin expression (Timmerman et al., 2003). Induction of EndoMT through TGF $\beta$ involves a pathway leading to an increase of Snail-1 through convergence of Smaddependent and Smad-independent signaling (Medici et al., 2011). TGF- $\beta 2$ drives EndoMT through a Smad-dependent activation of the myocardin-related transcription factor-A (MRTF-A) (Mihira et al., 2012). Snail up-regulation is delayed following TGF $\beta$ activation of EndoMT in cultured endothelial cells (Sobierajska et al., 2020). Smad independent pathways include MAPK/ERK/JNK (Medici et al., 2011; Heldin and Moustakas, 2011). Snail is also required for TGF $\beta$-induced EndoMT of embryonic stem cell-derived endothelial cells (Kokudo et al., 2008). Snail acts as a transcription factor of EndoMT induced by Smad-dependent and PI3K/p38-dependent signaling pathways (Medici et al., 2011). Hepatocyte growth factor (HGF)/cMet signaling prevents TGF $\beta$-1-induced EndoMT in cardiac fibrosis (Okayama et al., 2012; Wang et al., 2018).

FGF-2 inhibits EndoMT through miRNA-20a-mediated repression of TGF $\beta$ signaling (Correia et al., 2015). Otherwise, FGF-2 promotes TGF $\beta$-mediated EndoMT through regulation of let-7 miRNA expression (Chen et al., 2012). Tumor necrosis factor alpha (TNFa) enhances TGF $\beta$-induced EndoMT through TGF $\beta$ signal augmentation (Yoshimatsu et al., 2020).

During sprouting angiogenesis, an EndoMT is activated in endothelial cells to support the acquisition of mesenchymal features. VEGF and TGF $\beta$ may antagonize one another: exogenous VEGF treatment prevents TGF $\beta$-induced EndoMT during cardiac fibrosis (Illigens et al., 2017). Otherwise, human pulmonary valve progenitor cells exhibit EndoMT in response to VEGF-A and TGF $\beta$-2 (Paruchuri et al., 2006). Both Slug and Snail are involved in sprouting angiogenesis (Welch-Reardon et al., 2015). Slug is the primary initiator of this process, whereas the induction of Snail occurs later.

Hypoxia is an inducer of EndoMT through the regulation of the expression of TGF $\beta-1,-2$, and -3 (Caniggia et al., 2000; Hung et al., 2013). Hypoxia inducible factor 1 alpha (HIF-1a) induces EndoMT of human coronary endothelial cells and Snail is a direct target of HIF-1a ( Xu et al., 2015). Hypoxia induces the expression of Endo-MT-associated transcription factors Snail and Slug (Zhang et al., 2003).

\section{Therapeutic approaches}

As CSCs and EET promote VM in malignant tumors, doxycycline as an inhibitor of EMT and VM in hepatocellular carcinoma also prevents EET through methylation of the E-cadherin gene and downregulation of vimentin and VE-cadherin (Meng et al., 2014).

A conjugate of Temozolomide and perillyn alcohol inhibits EndoMT and reverts the mesenchymal phenotype of tumor-associated brain endothelial cells in glioblastoma (Marin-Ramos et al., 2019). Resistance to cisplatin and Getifinib in lung tumor spheroid model is reduced when EndoMT in endothelial cells is reversed, implying EndoMT as a resistance factor (Kim et al., 2019). Several drugs with anti-EndoMT properties have been approved for treatment of idiopathic pulmonary fibrosis, such as Nintedanib, a tyrosine kinase inhibitor of platelet derived growth factor (PDGF), FGF, and VEGF (Tsutsumi et al., 2019) and diabetic kidney disease, or Losartan, an inhibitor of TGFß-/Smad 2-3 pathway (Yao et al., 2018).

EndoMT in systemic sclerosis induced by endothelin-1 (ET-1) and TGF $\beta$ may be blocked by Macitentan, a dual ET-1 receptor antagonist (Cipriani et al., 2015). Vildagliptin, an anti-diabetic drug, ameliorates pulmonary fibrosis in lipopolysaccharide-induced lung injury by inhibiting EndoMT (Suzuki et al., 2017). Calcitriol, an active form of vitamin D3, reduces TGF $\beta$-Smad2-mediated EndoMT and fibroblast to myofibroblast transition (Tsai et al., 2019).

\section{Concluding Remarks}

EET is involved in transformation of tumor epithelial cells in endothelial cells and occurs during VM, i.e. cancer cell-derived channels like blood vessels, acting as alternative source of nutrient and oxygen supply and involved in tumor growth and invasion. Otherwise, EndoMT is involved in embryogenesis, tumor development, and contributes to resistance to cancer treatment. For example, in glioblastoma multiforme, chemoresistance is related to c-met-mediated EndoMT (Huang et al., 2016).

EET and EndoMT are controlled by complex signaling pathways. Different evidence suggests the existence of a complex signaling network involving TGF $\beta$, Wnt/ $\beta$-catenin and Notch pathways involved in the control of EndoMT. In this context, modulation of both EETEndoMT may contribute to counteract tumor progression and the molecular regulators of these two processes are potential targets and prognostic indicators. Single cell analysis of tumor cells may permit analysis of the different pathways involved in EET and EndoMT and differentiation between the molecular alterations underlying tumor progression and the different response to therapeutic agents. 


\section{References}

ARCINIEGAS E., SERVIN M., ARGÜELLO C., MOTA M. (1989). Development of the aorta in the chick embryo: structural and ultrastructural study. Atherosclerosis 76: 219-235. https://doi.org/10.1016/0021-9150(89)90106-8

ARCINIEGAS E., SUTTON A.B., ALLEN T.D., SCHOR A.M. (1992). Transforming growth factor beta 1 promotes the differentiation of endothelial cells into smooth muscle-like cells in vitro. Journal of Cell Science 103: 521-529. https:// doi.org/10.1242/jcs.103.2.521

ARCINIEGAS E., NEVES C. Y., CARRILLO L. M., ZAMBRANO E. A., RAMíREZ R. (2005). Endothelial-Mesenchymal Transition Occurs during Embryonic Pulmonary Artery Development. Endothelium 12: 193-200. https://doi. org/10.1080/10623320500227283

ARCINIEGAS E., FRID M. G., DOUGLAS I. S., STENMARK K. R. (2007). Perspectives on endothelial-to-mesenchymal transition: potential contribution to vascular remodeling in chronic pulmonary hypertension. American Journal of PhysiologyLung Cellular and Molecular Physiology 293: L1-L8. https://doi.org/10.1152/ ajplung.00378.2006

CANIGGIA I., MOSTACHFI H., WINTER J., GASSMANN M., LYE S. J., KULISZEWSK M., POST M. (2000). Hypoxia-inducible factor-1 mediates the biological effects of oxygen on human trophoblast differentiation through TGF $\beta 3$. Journal of Clinical Investigation 105: 577-587. https://doi.org/10.1172/JCl8316

CAO Y., FENG B., CHEN S., CHU Y., CHAKRABARTI S. (2014). Mechanisms of Endothelial to Mesenchymal Transition in the Retina in Diabetes. Investigative Opthalmology \& Visual Science 55: 7321. https://doi.org/10.1167/iovs.14-15167

CAO Y., QIAN C.-N. (2020). Vasculogenic mimicry. In Tumor Vascularization. Elsevier BV, pp. 89-100. https://doi.org/10.1016/b978-0-12-819494-2.00005-5

CHEN P.Y., QIN L., BARNES C., CHARISSE K., YI T., ZHANG X., ALI R., MEDINA P. P., YU J., SLACK F. J., ANDERSON D. G., KOTELIANSKI V., WANG F., TELLIDES G., SIMONS M. (2012). FGF Regulates TGF- $\beta$ Signaling and Endothelial-toMesenchymal Transition via Control of let-7 miRNA Expression. Cell Reports 2: 1684-1696. https://doi.org/10.1016/j.celrep.2012.10.021

CHOI S.H., KIM A.R., NAM J.K., KIM J.M., KIM J.Y., SEO H. R., LEE H.J., CHO J., LEE Y.J. (2018). Tumour-vasculature development via endothelial-to-mesenchymal transition after radiotherapy controls CD44v6+ cancer cell and macrophage polarization. Nature Communications 9: 5108. https://doi.org/10.1038/s41467018-07470-w

CIPRIANI P., DI BENEDETTO P., RUSCITTI P., CAPECE D., ZAZZERONI F., LIAKOULI V., PANTANO I., BERARDICURTI O., CARUBBI F., PECETTI G., TURRICCHIA S., ALESSE E., IGLARZ M., GIACOMELLI R. (2015). The Endothelial-mesenchymal Transition in Systemic Sclerosis Is Induced by Endothelin-1 and Transforming Growth Factor- $\beta$ and May Be Blocked by Macitentan, a Dual Endothelin-1 Receptor Antagonist. The Journal of Rheumatology 42: 1808-1816. https://doi.org/10.3899/ jrheum. 150088

COOLEY B. C., NEVADO J., MELLAD J., YANG D., ST. HILAIRE C., NEGRO A., FANG F., CHEN G., SAN H., WALTS A. D., SCHWARTZBECK R. L., TAYLOR B., LANZER J. D., WRAGG A., ELAGHA A., BELTRAN L. E., BERRY C., FEIL R., VIRMANI R., LADICH E., KOVACIC J. C., BOEHM M. (2014). TGF- $\beta$ Signaling Mediates Endothelial-to-Mesenchymal Transition (EndMT) During Vein Graft Remodeling. Science Translational Medicine 6:227ra34. https://doi.org/10.1126/ scitranslmed.3006927

CORREIA A. C.P., MOONEN J.R. A.J., BRINKER M. G.L., KRENNING G. (2015). FGF2 inhibits Endothelial-Mesenchymal Transition through microRNA-20a-mediated repression of canonical TGF- $\beta$ Signaling. Journal of Cell Science 129: 569-579. https://doi.org/10.1242/jcs.176248

DUDLEY A. C. (2012). Tumor Endothelial Cells. Cold Spring Harbor Perspectives in Medicine 2: a006536-a006536. https://doi.org/10.1101/cshperspect.a006536

FAN C.S., CHEN W.S., CHEN L.L., CHEN C.C., HSU Y.T., CHUA K. V., WANG H.D., HUANG T.S. (2017). Osteopontin-integrin engagement induces HIF-1a-TCF12mediated endothelial-mesenchymal transition to exacerbate colorectal cancer. Oncotarget 9: 4998-5015. https://doi.org/10.18632/oncotarget.23578

FAN CHI-SHUAN, CHEN WEI-SHONE, CHEN LI-LI, CHEN CHIA-CHI, HSU YU-TING, CHUA KEE VOON, WANG HORNG-DAR, HUANG TZE-SING (2018). Osteopontinintegrin engagement induces HIF-1a-TCF12-mediated endothelial-mesenchymal transition to exacerbate colorectal cancer. Oncotarget 9: 4998-5015. https://doi. org/10.18632/oncotarget.23578
FAN C.S., CHEN L.L., HSU T.A., CHEN C.C., CHUA K. V., LI C.P., HUANG T.S. (2019) Endothelial-mesenchymal transition harnesses HSP90a-secreting M2-macrophages to exacerbate pancreatic ductal adenocarcinoma. Journal of Hematology \& Oncology 12: 138. https://doi.org/10.1186/s13045-019-0826-2

FRIEDL P., GILMOUR D. (2009). Collective cell migration in morphogenesis, regeneration and cancer. Nature Reviews Molecular Cell Biology 10: 445-457. https:// doi.org/10.1038/nrm2720

GRANATA S., BENEDETTI C., GAMBARO G., ZAZA G. (2020). Kidney allograft fibrosis: what we learned from latest translational research studies. Journal of Nephrology 33: 1201-1211. https://doi.org/10.1007/s40620-020-00726-z

HASHIMOTO N., PHAN S. H., IMAIZUMI K., MATSUO M., NAKASHIMA H., KAWABE T., SHIMOKATA K., HASEGAWA Y. (2010). Endothelial-Mesenchymal Transition in Bleomycin-Induced Pulmonary Fibrosis. American Journal of Respiratory Cell and Molecular Biology 43: 161-172. https://doi.org/10.1165/rcmb.2009-00310C

HELDIN C.H., MOUSTAKAS A. (2011). Role of Smads in TGF $\beta$ signaling. Cell and Tissue Research 347: 21-36. https://doi.org/10.1007/s00441-011-1190-x

HONG L., DU X., LI W., MAO Y., SUN L., LI X. (2018). EndMT: A promising and controversial field. European Journal of Cell Biology 97: 493-500. https://doi. org/10.1016/j.ejcb.2018.07.005

HOPPER R. K., MOONEN J.R. A.J., DIEBOLD I., CAO A., RHODES C. J., TOJAIS N. F., HENNIGS J. K., GU M., WANG L., RABINOVITCH M. (2016). In Pulmonary Arterial Hypertension, Reduced BMPR2 Promotes Endothelial-to-Mesenchymal Transition via HMGA1 and Its Target Slug. Circulation 133: 1783-1794. https:// doi.org/10.1161/CIRCULATIONAHA.115.020617

HUANG M., LIU T., MA P., MITTEER R. A., ZHANG Z., KIM H. J., YEO E., ZHANG D, CAI P., LI C., ZHANG L., ZHAO B., ROCCOGRANDI L., O'ROURKE D. M., DAH MANE N., GONG Y., KOUMENIS C., FAN Y. (2016). c-Met-mediated endothelia plasticity drives aberrant vascularization and chemoresistance in glioblastoma. Journal of Clinical Investigation 126:1801-1814. https://doi.org/10.1172/JCI84876

HUANG M., ZHANG D., WU J. Y., XING K., YEO E., LI C., ZHANG L., HOLLAND E., YAO L., QIN L., BINDER Z. A., O'ROURKE D. M., BREM S., KOUMENIS C., GONG Y., FAN Y. (2020). Wnt-mediated endothelial transformation into mesenchymal stem cell-like cells induces chemoresistance in glioblastoma. Science Translational Medicine 12: 532. https://doi.org/10.1126/scitransImed.aay7522

HUNG S.P., YANG M.H., TSENG K.F., LEE O. K. (2013). Hypoxia-Induced Secretion of TGF- $\beta 1$ in Mesenchymal Stem Cell Promotes Breast Cancer Cell Progression. Cell Transplantation 22: 1869-1882. https://doi.org/10.3727/096368912X657954

ILLIGENS B. M.W., CASAR BERAZALUCE A., POUTIAS D., GASSER R., DEL NIDO P. J., FRIEHS I. (2017). Vascular Endothelial Growth Factor Prevents Endothelialto-Mesenchymal Transition in Hypertrophy. The Annals of Thoracic Surgery 104 932-939. https://doi.org/10.1016/j.athoracsur.2017.01.112

KALLURI R., WEINBERG R. A. (2009). The basics of epithelial-mesenchymal transition. Journal of Clinical Investigation 119:1420-1428. https://doi.org/10.1172/JCI39104

KIM S.H., SONG Y., SEO H. R. (2019). GSK-3ß regulates the endothelial-to-mesenchyma transition via reciprocal crosstalk between NSCLC cells and HUVECs in multicellular tumor spheroid models. Journal of Experimental \& Clinical Cancer Research 38: 46. https://doi.org/10.1186/s13046-019-1050-1

KOKUDO T., SUZUKI Y., YOSHIMATSU Y., YAMAZAKI T., WATABE T., MIYAZONO K (2008). Snail is required for TGF $\beta$-induced endothelial-mesenchymal transition of embryonic stem cell-derived endothelial cells. Journal of Cell Science 121 3317-3324. https://doi.org/10.1242/jcs.028282

KOVACIC J. C., MERCADER N., TORRES M., BOEHM M., FUSTER V. (2012). Epithelialto-Mesenchymal and Endothelial-to-Mesenchymal Transition. Circulation 125: 1795-1808. https://doi.org/10.1161/CIRCULATIONAHA.111.040352

LI J., QU X., BERTRAM J. F. (2009). Endothelial-Myofibroblast Transition Contributes to the Early Development of Diabetic Renal Interstitial Fibrosis in StreptozotocinInduced Diabetic Mice. The American Journal of Pathology 175: 1380-1388. https:// doi.org/10.2353/ajpath.2009.090096

LIU T., MA W., XU H., HUANG M., ZHANG D., HE Z., ZHANG L., BREM S., O'ROURKE D. M., GONG Y., MOU Y., ZHANG Z., FAN Y. (2018). PDGF-mediated mesenchymal transformation renders endothelial resistance to anti-VEGF treatment in glioblastoma. Nature Communications 9:3439. https://doi.org/10.1038/s41467-018-05982-z

MA W., WANG Y., ZHANG R., YANG F., ZHANG D., HUANG M., ZHANG L., DORSEY J. F., BINDER Z. A., O'ROURKE D. M., FRAIETTA J. A., GONG Y., FAN Y. (2021). Targeting PAK4 to reprogram the vascular microenvironment and improve CAR-T immunotherapy for glioblastoma. Nature Cancer2:83-97. https://doi.org/10.1038/ s43018-020-00147-8 
MAN S., SANCHEZ DUFFHUES G., TEN DIJKE P., BAKER D. (2018). The therapeutic potential of targeting the endothelial-to-mesenchymal transition. Angiogenesis 22: 3-13. https://doi.org/10.1007/s10456-018-9639-0

MANETTI M., ROMANO E., ROSA I., GUIDUCCI S., BELLANDO-RANDONE S., DE PAULIS A., IBBA-MANNESCHI L., MATUCCI-CERINIC M. (2017). Endothelialto-mesenchymal transition contributes to endothelial dysfunction and dermal fibrosis in systemic sclerosis. Annals of the Rheumatic Diseases 76: 924-934. https://doi.org/10.1136/annrheumdis-2016-210229

MANIOTIS A. J., FOLBERG R., HESS A., SEFTOR E. A., GARDNER L. M.G., PE'ER J., TRENT J. M., MELTZER P. S., HENDRIX M. J.C. (1999). Vascular Channel Formation by Human Melanoma Cells in Vivo and in Vitro: Vasculogenic Mimicry. The American Journal of Pathology 155: 739-752. https://doi.org/10.1016/ S0002-9440(10)65173-5

MARÍN-RAMOSN. I., JHAVERI N., THEINT.Z., FAYNGOR R. A., CHENT. C., HOFMAN F. M. (2019). NEO212, a conjugate of temozolomide and perillyl alcohol, blocks the endothelial-to-mesenchymal transition in tumor-associated brain endothelial cells in glioblastoma. Cancer Letters 442: 170-180. https://doi.org/10.1016/j. canlet.2018.10.034

MARKWALD R. R., FITZHARRIS T. P., SMITH W. N.A. (1975). Structural analysis of endocardial cytodifferentiation. Developmental Biology 42: 160-180. https://doi. org/10.1016/0012-1606(75)90321-8

MEDICI D., POTENTA S., KALLURI R. (2011). Transforming growth factor- $\beta 2$ promotes Snail-mediated endothelial-mesenchymal transition through convergence of Smad-dependent and Smad-independent signalling. Biochemical Journal 437: 515-520. https://doi.org/10.1042/BJ20101500

MEDICI D., KALLURI R. (2012). Endothelial-mesenchymal transition and its contribution to the emergence of stem cell phenotype. Seminars in Cancer Biology 22: 379-384. https://doi.org/10.1016/j.semcancer.2012.04.004

MENDOZA F. A., PIERA-VELAZQUEZ S., FARBER J. L., FEGHALI-BOSTWICK C., JIMÉNEZ S. A. (2015). Endothelial Cells Expressing Endothelial and Mesenchymal Cell Gene Products in Lung Tissue From Patients With Systemic SclerosisAssociated Interstitial Lung Disease. Arthritis \& Rheumatology 68: 210-217. https:// doi.org/10.1002/art.39421

MENG J., SUN B., ZHAO X., ZHANG D., ZHAO X., GU Q., DONG X., ZHAO N., LIU P. LIUY. (2014). Doxycycline as an Inhibitor of the Epithelial-to-Mesenchymal Transition and Vasculogenic Mimicry in Hepatocellular Carcinoma. Molecular Cancer Therapeutics 13: 3107-3122. https://doi.org/10.1158/1535-7163.MCT-13-1060

MIHIRA H., SUZUKI H. I., AKATSU Y., YOSHIMATSU Y., IGARASHI T., MIYAZONO K., WATABE T. (2012). TGF- $\beta$-induced mesenchymal transition of MS-1 endothelial cells requires Smad-dependent cooperative activation of Rho signals and MRTFA. The Journal of Biochemistry 151:145-156. https://doi.org/10.1093/jb/mvr121

MINTET E., RANNOU E., BUARD V., WEST G., GUIPAUD O., TARLET G., SABOURIN J.C., BENDERITTER M., FIOCCHI C., MILLIAT F., FRANÇOIS A. (2015). Identification of Endothelial-to-Mesenchymal Transition as a Potential Participant in Radiation Proctitis. The American Journal of Pathology 185: 2550-2562. https:// doi.org/10.1016/j.ajpath.2015.04.028

NAKAJIMA Y., MIRONOV V., YAMAGISHI T., NAKAMURA H., MARKWALD R. R. (1997). Expression of smooth muscle alpha-actin in mesenchymal cells during formation of avian endocardial cushion tissue: A role for transforming growth factor B3. Developmental Dynamics 209: 296-309. https://doi.org/10.1002/ (SICI)1097-0177(199707)209:3<296::AID-AJA5>3.0.CO;2-D

NIE L., LYROS O., MEDDA R., JOVANOVIC N., SCHMIDT J. L., OTTERSON M. F., JOHNSON C. P., BEHMARAM B., SHAKER R., RAFIEE P. (2014). Endothelialmesenchymal transition in normal human esophageal endothelial cells cocultured with esophageal adenocarcinoma cells: role of IL-1 $\beta$ and TGF- $\beta 2$. American Journal of Physiology-Cell Physiology 307: C859-C877. https://doi.org/10.1152/ ajpcell.00081.2014

OKAYAMA K., AZUMA J., DOSAKA N., IEKUSHI K., SANADA F., KUSUNOKI H., IWABAYASHI M., RAKUGI H., TANIYAMA Y., MORISHITA R. (2012). Hepatocyte Growth Factor Reduces Cardiac Fibrosis by Inhibiting Endothelial-Mesenchymal Transition. Hypertension 59: 958-965. https://doi.org/10.1161/HYPERTENSIONAHA.111.183905

PARDALI E., SANCHEZ-DUFFHUES G., GOMEZ-PUERTO M., TEN DIJKE P. (2017). TGF- $\beta$-Induced Endothelial-Mesenchymal Transition in Fibrotic Diseases. International Journal of Molecular Sciences 18: 2157. https://doi.org/10.3390/ ijms18102157
PARUCHURI S., YANG J.H., AIKAWA E., MELERO-MARTIN J. M., KHAN Z. A., LOUKOGEORGAKIS S., SCHOEN F. J., BISCHOFF J. (2006). Human Pulmonary Valve Progenitor Cells Exhibit Endothelial/Mesenchymal Plasticity in Response to Vascular Endothelial Growth Factor-A and Transforming Growth Factor- $\beta 2$ 2. Circulation Research 99:861-869. https://doi.org/10.1161/01.RES.0000245188.41002.2c

RIBATTI D., CRIVELLATO E. (2012). "Sprouting angiogenesis", a reappraisal. Developmental Biology 372: 157-165. https://doi.org/10.1016/j.ydbio.2012.09.018

RIBATTI D. (2017). Epithelial-mesenchymal transition in morphogenesis, cancer progression and angiogenesis. Experimental Cell Research 353: 1-5. https://doi. org/10.1016/j.yexcr.2017.02.041

SOBIERAJSKAK.,CISZEWSKIW.M.,MACIERZYNSKA-PIOTROWSKAE.,KLOPOCKA W., PRZYGODZKA P., KARAKULA M.,PESTKA K., WAWRO M. E., NIEWIAROWSKA J. (2020). The New Model of Snail Expression Regulation: The Role of MRTFs in Fast and Slow Endothelial-Mesenchymal Transition. International Journal of Molecular Sciences 21: 5875. https://doi.org/10.3390/ijms21165875

SOUILHOL C., HARMSEN M. C., EVANS P. C., KRENNING G. (2018). Endothelialmesenchymal transition in atherosclerosis. Cardiovascular Research 114:565-577. https://doi.org/10.1093/cvr/cvx253

SUN B., ZHANG D., ZHAO N., ZHAO X. (2016). Epithelial-to-endothelial transition and cancer stem cells: two cornerstones of vasculogenic mimicry in malignant tumors. Oncotarget 8: 30502-30510. https://doi.org/10.18632/oncotarget.8461

SUN T., ZHAO N., ZHAO X., GU Q., ZHANG S., CHE N., WANG X., DU J., LIU Y., SUN B. (2010). Expression and functional significance of Twist1 in hepatocellular carcinoma: Its role in vasculogenic mimicry. Hepatology 51: 545-556. https:// doi.org/10.1002/hep.23311

SUN T., SUN B., ZHAO X., ZHAO N., DONG X., CHE N., YAO Z., MA Y., GU Q., ZONG W., LIU Z. (2011). Promotion of tumor cell metastasis and vasculogenic mimicry by way of transcription coactivation by Bcl-2 and Twist1: A study of hepatocellular carcinoma. Hepatology 54: 1690-1706. https://doi.org/10.1002/hep.24543

SUZUKI T., TADA Y., GLADSON S., NISHIMURA R., SHIMOMURA I., KARASAWA S., TATSUMI K., WEST J. (2017). Vildagliptin ameliorates pulmonary fibrosis in lipopolysaccharide-induced lung injury by inhibiting endothelial-to-mesenchymal transition. Respiratory Research 18: 177

TIMMERMAN L. A., GREGO-BESSA J., RAYA A., BERTRÁN E., PÉREZ-POMARES J M., DÍEZ J., ARANDA S., PALOMO S., MCCORMICK F., IZPISÚA-BELMONTE J. C., DE LA POMPA J. L. (2003). Notch promotes epithelial-mesenchymal transition during cardiac development and oncogenic transformation. Genes \& Development 18: 99-115. https://doi.org/10.1101/gad.276304

TOMBOR L. S., JOHN D., GLASER S. F., LUXÁN G., FORTE E., FURTADO M., ROSENTHAL N., BAUMGARTEN N., SCHULZ M. H., WITTIG J., ROGG E.-M., MANAVSKI Y., FISCHER A., MUHLY-REINHOLZ M., KLEE K., LOOSO M., SELIGNOW C., ACKER T., BIBLI S.-I., FLEMING I., PATRICK R., HARVEY R. P., ABPLANALP W. T., DIMMELER S. (2021). Single cell sequencing reveals endothelial plasticity with transient mesenchymal activation after myocardial infarction. Nature Communications 12: 681. https://doi.org/10.1038/s41467-021-20905-1

TSAI T.H., LEE C.H., CHENG C.I., FANG Y.N., CHUNG S.Y., CHEN S.M., LIN C.J., WU C.J., HANG C.L., CHEN W.Y. (2019). Liraglutide Inhibits Endothelial-toMesenchymal Transition and Attenuates Neointima Formation after Endovascular Injury in Streptozotocin-Induced Diabetic Mice. Cells 8: 589. https://doi. org/10.3390/cells8060589

TSUTSUMI T., NAGAOKA T., YOSHIDA T., WANG L., KURIYAMA S., SUZUKI Y., NA GATA Y., HARADA N., KODAMA Y., TAKAHASHI F., MORIO Y., TAKAHASHI K. (2019). Nintedanib ameliorates experimental pulmonary arterial hypertension via inhibition of endothelial mesenchymal transition and smooth muscle cell proliferation. PLOS ONE 14: e0214697. https://doi.org/10.1371/journal.pone.0214697

TUDER R. M., GROVES B., BADESCH D. B., VOELKEL N. F. (1994). Exuberant endothelial cell growth and elements of inflammation are present in plexiform lesions of pulmonary hypertension.. The American journal of pathology 144: 275-285.

WANG Z., FEI S., SUO C., HAN Z., TAO J., XU Z., ZHAO C., TAN R., GU M. (2018). Antifibrotic Effects of Hepatocyte Growth Factor on Endothelial-to-Mesenchymal Transition via Transforming Growth Factor-Beta 1 (TGF- $\beta 1$ )/Smad and Akt/mTOR/ P70S6K Signaling Pathways. Annals of Transplantation 23: 1-10. https://doi. org/10.12659/АОТ.906700

WAWRO M., CHOJNACKA K., WIECZOREK-SZUKAŁA K., SOBIERAJSKA K., NIEWIAROWSKA J. (2018). Invasive Colon Cancer Cells Induce Transdifferentiation of Endothelium to Cancer-Associated Fibroblasts through Microtubules Enriched in Tubulin- $\beta 3$. International Journal of Molecular Sciences 20: 53. https://doi. org/10.3390/ijms20010053 


\section{Domenico Ribatti}

WELCH-REARDON K. M., WU N., HUGHES C. C.W. (2015). A Role for Partial Endothelial-Mesenchymal Transitions in Angiogenesis?. Arteriosclerosis, Thrombosis, and Vascular Biology 35: 303-308. https://doi.org/10.1161/ATVBAHA.114.303220

WIDYANTORO B., EMOTO N., NAKAYAMA K., ANGGRAHINI D. W., ADIARTO S., IWASA N., YAGI K., MIYAGAWA K., RIKITAKE Y., SUZUKI T., KISANUKI Y. Y. YANAGISAWA M., HIRATA K. (2010). Endothelial Cell-Derived Endothelin-1 Promotes Cardiac Fibrosis in Diabetic Hearts Through Stimulation of Endothelialto-Mesenchymal Transition. Circulation 121:2407-2418. https://doi.org/10.1161/ CIRCULATIONAHA.110.938217

XAVIER S., VASKO R., MATSUMOTO K., ZULLO J. A., CHEN R., MAIZEL J., CHANDER P. N., GOLIGORSKY M. S. (2014). Curtailing Endothelial TGF- $\beta$ Signaling Is Sufficient to Reduce Endothelial-Mesenchymal Transition and Fibrosis in CKD . Journal of the American Society of Nephrology 26: 817-829. https://doi. org/10.1681/ASN.2013101137

XIAO L., KIM D. J., DAVIS C. L., MCCANN J. V., DUNLEAVEY J. M., VANDERLINDEN A. K., XU N., PATTENDEN S. G., FRYE S. V., XU X., ONAITIS M., MONAGHANBENSON E., BURRIDGE K., DUDLEY A. C. (2015). Tumor Endothelial Cells with Distinct Patterns of TGF $\beta$-Driven Endothelial-to-Mesenchymal Transition. Cancer Research 75: 1244-1254. https://doi.org/10.1158/0008-5472.CAN-14-1616

XIAO T., ZHANG Q., ZONG S., ZHONG W., QIN Y., BI Z., CHEN S., LIU H., WEI J. ZHOU B., WANG L., ZHOU H., LIU Y., SUN T., YANG C. (2018). Protease-activated receptor-1 (PAR1) promotes epithelial-endothelial transition through Twist1 in hepatocellular carcinoma. Journal of Experimental \& Clinical Cancer Research 37: 185. https://doi.org/10.1186/s13046-018-0858-4

XU X., TAN X., TAMPE B., SANCHEZ E., ZEISBERG M., ZEISBERG E. M. (2015). Snail Is a Direct Target of Hypoxia-inducible Factor 1a (HIF1a) in Hypoxia-induced Endothelial to Mesenchymal Transition of Human Coronary Endothelial Cells. Journal of Biological Chemistry 290:16653-16664. https://doi.org/10.1074/jbc.M115.636944

YAMADA N. O., HEISHIMA K., AKAO Y., SENDA T. (2019). Extracellular Vesicles Containing MicroRNA-92a-3pFacilitatePartial Endothelial-Mesenchymal Transition and Angiogenesis in Endothelial Cells. International Journal of Molecular Sciences 20: 4406. https://doi.org/10.3390/ijms20184406

YANG J., LUY., LIN Y.Y., ZHENG Z.Y., FANG J.H., HE S., ZHUANG S.M. (2016). Vascular mimicry formation is promoted by paracrine TGF- $\beta$ and SDF1 of cancer-associated fibroblasts and inhibited by miR-101 in hepatocellular carcinoma. Cancer Letters 383: 18-27. https://doi.org/10.1016/j.canlet.2016.09.012
YAO Y., LI Y., ZENG X., YE Z., LI X., ZHANG L. (2018). Losartan Alleviates Rena Fibrosis and Inhibits Endothelial-to-Mesenchymal Transition (EMT) Under HighFat Diet-Induced Hyperglycemia. Frontiers in Pharmacology 9: 1213. https://doi. org/10.3389/fphar.2018.01213

YOSHIMATSU Y., WAKABAYASHI I., KIMURO S., TAKAHASHI N., TAKAHASHI K., KOBAYASHI M., MAISHI N., PODYMA-INOUE K. A., HIDA K., MIYAZONO K. WATABE T. (2020). TNF-a enhances TGF- $\beta$-induced endothelial-to-mesenchymal transition via TGF- $\beta$ signal augmentation. Cancer Science 111:2385-2399. https:// doi.org/10.1111/cas.14455

ZEISBERG E. M., TARNAVSKI O., ZEISBERG M., DORFMAN A. L., MCMULLEN J. R., GUSTAFSSON E., CHANDRAKER A., YUAN X., PU W. T., ROBERTS A. B., NEILSON E. G., SAYEGH M. H., IZUMO S., KALLURI R. (2007a). Endothelialto-mesenchymal transition contributes to cardiac fibrosis. Nature Medicine 13: 952-961. https://doi.org/10.1038/nm1613

ZEISBERG E. M., POTENTA S., XIE L., ZEISBERG M., KALLURI R. (2007b). Discovery of Endothelial to Mesenchymal Transition as a Source for Carcinoma-Associated Fibroblasts. Cancer Research 67: 10123-10128. https://doi.org/10.1158/00085472.CAN-07-3127

ZEISBERG M., NEILSON E. G. (2009). Biomarkers for epithelial-mesenchymal transitions. Journal of Clinical Investigation 119: 1429-1437. https://doi.org/10.1172/ $\mathrm{JCl} 36183$

ZEISBERG E. M., POTENTA S. E., SUGIMOTO H., ZEISBERG M., KALLURI R. (2008) Fibroblasts in Kidney Fibrosis Emerge via Endothelial-to-Mesenchymal Transition . Journal of the American Society of Nephrology 19: 2282-2287. https://doi. org/10.1681/ASN.2008050513

ZHANG H., AKMAN H. O., SMITH E. L. P., ZHAO J., MURPHY-ULLRICH J E., BATUMAN O. A. (2003). Cellular response to hypoxia involves signaling via Smad proteins. Blood 101: 2253-2260. https://doi.org/10.1182/ blood-2002-02-0629

ZHANG D., SUN B., ZHAO X., MA Y., JI R., GU Q., DONG X., LI J., LIU F., JIA X., LENG X., ZHANG C., SUN R., CHI J. (2014). Twist1 expression induced by sunitinib accelerates tumor cell vasculogenic mimicry by increasing the population of CD133+ cells in triple-negative breast cancer. Molecular Cancer 13: 207. https:// doi.org/10.1186/1476-4598-13-207 